\title{
A Biometric Description of Common Dormice from Gorce (Beskid Wysoki Mts), Southern Poland
}

\author{
CHARAKTERYSTYKA BIOMETRYCZNA ORZESZNIC Z GORCÓW (BESKID WYSOKI)
}

\section{Ireneusz BIA£AS Włodzimierz CHĘTNICKI \& Janusz KUPRYJANOWICZ}

Białas I., Chętnicki W. \& Kupryjanowicz J., 1989: A biometric description of common dormice from Gorce (Beskid Wysoki, Mts), Southern Poland. Acta theriol., 34, 43: 648-651 [With 1 Table]

Of 2526 small mammals, twenty-nine common dormice, Muscardinus avellanarius (Linnaeus, 1758), were caught in Gorce National Park from 1981 till 1983. It was ascertained that average body and skull measurements of $M$. avellanarius from the Gorce were greater than those of animals from other Polish populations. The average body weight of mature females was $19.5 \mathrm{~g}$ and was significantly higher than the body weight of mature males $(16.0 \mathrm{~g})$, whereas a male hindfoot was significantly longer $(17.0 \mathrm{~mm})$ than a female hindfoot $(15.8 \mathrm{~mm})$.

[Department of Biology, Warsaw University Branch, Świerkowa 20B, 15-950 Białystok, Poland]

\section{INTRODUCTION}

The common dormouse in the mountainous regions of Poland have been found in the West Sudety (Chudoba et al., 1973), West Beskidy (Chudoba \& Humiński, 1968; Chudoba \& Haitlinger, 1971; Haitlinger \& Szyszka, 1975; Haitlinger \& Szyszka, 1977; Juchiewicz et al., 1986) and East Beskidy (Grodziński, 1957; Buchalczyk \& Markowski, 1979). However, little is known about this species. Craniometric features of this group of animals, which occur in mountainous regions as well as in the remaining parts of Poland (Sidorowicz, 1959; Buchalczyk \& Markowski, 1979; Białas et al., 1982; Kałuża, 1987) have not been thoroughly described. Our aim was to present biometric features of cormice from the Gorce.

\section{MATERIAL AND METHODS}

Small mammals were caught in Gorce National Park at the end of August and the beginning of September from 1981 till 1983. Mammals were caught with pitfalls and map traps using wicks soaked in browned oil and flour as bait. The pitfalls were placed in different biotopes, 20 pitfalls in a line every $12 \mathrm{~m}$, and 40 snap traps (in twos at a pitfall). Generally there were 79 catching lines placed in the Gorce area $(28,440$ trap-nights). The variety of examined biotopes was described in the work on small mammals of Gorce National Park (Białas et al., 1989). Twenty-nine dormice were among 2526 small mammals caught there. Animals were weighed with accuracy to $0.1 \mathrm{~g}$. Also their sex and 
sexual activity were determined. The statistical significance of differences between the averages of respective measurements was checked by the $t$-Student test at $\alpha=0.05$.

\section{RESULTS AND DISCUSSION}

In the years $1981,1982,1983$, respectively, 15,3 and $11 \mathrm{M}$. avellanarius were caught in both deciduous and coniferous forests: 3 in Alnetum incanae, 11 in Fagetum carpaticum, 3 in Abieti-Piceetum montanum 4 in Fagetum carpaticum /Piceetum tatricum, (in the ecotone), and 7 in Piceetum tatricum. One $M$. avellanarius was caught on the wet meadow Cirsietum rivularis. The fact that dormice left the wood was observed earlier (Chudoba \& Humiński, 1968; Haitlinger \& Szyszka, 1977).

The body dimensions of dormice caught in the Gorce were comparable to those of that species from other areas of Poland (Pucek, 1984), of Czechoslovakia (Pelikán et al., 1979) and of Northern Europe (Siivonen, 1979). However, M. avellanarius from the Gorce had greater head and body lengths (about $3 \mathrm{~mm}$ greater) and longer hindfeet than animals of that species from Kampinos Forest (Sidorowicz, 1959).

Table 1

Biometrical measurements of Muscardinus avellanarius caught in Gorce National Park in 1981-1983 (linear measurements in mm; mean value \pm SD) $\mathrm{N}_{1}$ - number of morphometrical measurements, $\mathrm{N}_{2}$ - number of craniometrical measurements. Abbreviations of cranial measurements: $\mathrm{CbL}$ - condylobasal length; ZyB - zygomatic breadth; $\mathrm{BcB}$ - brain-case breadth; $\mathrm{BcHp}$ - brain - case height per bullae; $\mathrm{BcHb}$ - brain - case height between bullae; IC - interorbital constriction; UTRL - upper tooth row length; LTRL - lower tooth row length; DL - diastema length; MdL - mandibular length. ${ }^{*}$ The differences between neighbouring values are statistically significant $(t-$ test; $\alpha=0.05$ ).

\begin{tabular}{|c|c|c|c|c|c|}
\hline \multirow{2}{*}{ Measurement } & \multicolumn{4}{|c|}{ Adultus } & \multirow{2}{*}{ Subadultus } \\
\hline & Males & & Females & Total & \\
\hline $\mathrm{N}_{1}$ & 5 & & 4 & 9 & 12 \\
\hline $\begin{array}{l}\text { Body weight (g) } \\
\text { Head \& body length } \\
\text { Tail length } \\
\text { Hindfoot length } \\
\text { Ear height }\end{array}$ & $\begin{array}{l}16.0 \pm 2.2 \\
77.4 \pm 3.5 \\
71.8 \pm 4.2 \\
17.0 \pm 0.4 \\
13.0 \pm 0.5\end{array}$ & * & $\begin{array}{l}19.5 \pm 1.7 \\
79.9 \pm 2.8 \\
72.7 \pm 6.0 \\
15.8 \pm 0.6 \\
13.1 \pm 0.5\end{array}$ & $\begin{array}{l}17.6 \pm 2.6 \\
78.5 \pm 3.3 \\
72.2 \pm 4.8 \\
16.4 \pm 0.8 \\
13.0 \pm 0.4\end{array}$ & $\begin{array}{ll}* & 12.6 \pm 5.1 \\
* & 66.7 \pm 6.2 \\
* & 65.9 \pm 7.0 \\
& 16.2 \pm 0.8 \\
* & 11.5 \pm 1.2\end{array}$ \\
\hline $\mathrm{N}_{2}$ & 2 & & 4 & 6 & 5 \\
\hline $\begin{array}{l}\text { CbL } \\
\text { ZyB } \\
\text { BcB } \\
\text { BcHp } \\
\text { BcHb } \\
\text { IC } \\
\text { UTRL } \\
\text { LTRL } \\
\text { DL } \\
\text { MdL }\end{array}$ & $\begin{array}{r}21.1 \pm 0.8 \\
12.8 \pm 0.5 \\
11.6 \pm 0.2 \\
9.4 \pm 0.1 \\
8.2 \pm 0.6 \\
3.6 \pm 0.1 \\
4.9 \pm 0.1 \\
4.7 \pm 0.1 \\
5.5 \pm 0.1 \\
11.6 \pm 0.0\end{array}$ & $\begin{array}{l}* \\
*\end{array}$ & $\begin{array}{r}22.1 \pm 0.5 \\
13.8 \pm 0.3 \\
11.9 \pm 0.2 \\
9.5 \pm 0.2 \\
8.0 \pm 0.2 \\
3.4 \pm 0.2 \\
4.7 \pm 0.1 \\
4.6 \pm 0.1 \\
6.4 \pm 0.2 \\
12.1 \pm 0.2\end{array}$ & $\begin{array}{r}21.8 \pm 0.8 \\
13.4 \pm 0.6 \\
11.8 \pm 0.3 \\
9.4 \pm 0.2 \\
8.1 \pm 0.2 \\
3.5 \pm 0.1 \\
4.8 \pm 0.1 \\
4.6 \pm 0.1 \\
6.1 \pm 0.5 \\
11.9 \pm 0.3\end{array}$ & $\begin{array}{rr}* & 19.4 \pm 1.1 \\
* & 11.9 \pm 0.5 \\
* & 11.2 \pm 0.3 \\
* & 8.9 \pm 0.2 \\
& 7.8 \pm 0.4 \\
& 3.5 \pm 0.1 \\
& 4.7 \pm 0.1 \\
& 4.6 \pm 0.2 \\
* \quad 5.3 \pm 0.3 \\
* \quad 11.0 \pm 0.5\end{array}$ \\
\hline
\end{tabular}


They were also heavier and had longer head and body lengths (about $6 \mathrm{~mm}$ for females and $1 \mathrm{~mm}$ for males) and hindfeet lengths than the dormice caught in West Bieszczady Mts (Buchalczyk \& Markowski, 1979). Also ear height noted in $M$. avellanarius from other areas of Poland (Sidorowicz, 1959; Pucek, 1984) and Czechoslovakia (Pelikan et al., 1979) was smaller than the data presented in this work.

Skull measurements of mature $M$. avellanarius in general agreed with those given for dormice from other Polish populations, however, the averages $\mathrm{CbL}, \mathrm{BcB}$ and $\mathrm{DL}$ (for explanation of abbreviations see Table 1) of dormice from the Gorce were greater than the average values of those measurements of dormic from Kampinos Forest (Sicorowicz, 1959). On the other hand immature animals from the Gorce were smaller than the immature dormice from Knyszyn Forest, except the values of measurements IC, UTRL and LTRL which were similar in both populations (Białas et al., 1982).

Among mature males and females of dormice from the Gorce there were statistically significant differences in body weight (females were heavier) and in hindfood length. The average hindfood length of males was about $1.2 \mathrm{~mm}$ longer than that of females. The values of other body measurements were smaller in males than in females (Table 1). A reversed tendency was observed in the population of dormice from West Bieszczady Mts where males were larger than females (Buchalczyk \& Markowski, 1979).

The hindfood length, which was significantly greater in males than in females, did not differ when mature animals were compared with immature ones. It seems to be a feature connected with sex. From among craniometric features $\mathrm{ZyB}, \mathrm{DL}$ and $\mathrm{MdL}$ were significantly greater in females than in males (this also indicates that females in the examined populations were larger than males) and in mature individuals in comparison with immature ones. The measurements of $\mathrm{ClL}$, $\mathrm{BcB}$ and $\mathrm{BcHp}$ were significantly greater in mature animals than in immature ones (Table 1).

On the basis of results we can assume that $M$. avellanarius from a mountainous population were a little bigger than animals from lowland populations. A similar relationship in Clethrionomys glareolus (Schreber, 1780) was observed by Haitlinger (1970). Morpho- and craniometric features seem to indicate that female dormice caught in the Gorce were larger than males. We may suspect that some of these parameters are connected with sex whereas others, with the age of the examined animals. However, the small sample size used for the analysis does not allow too far reaching conclusions.

Acknowledgment: The authors want to thank the students, members of Biology Club at 
the Department of Biology, Warsaw University Branch in Białystok, for their help in catching the small mammals in very difficult field conditions.

\section{REFERENCES}

Białas I., Chętnicki W. \& Kupryjanowicz J., 1982: Pilchowate (Gliridae) w Puszczy Knyszyńskiej. Przegl. zool., 26: 465-469. - Białas I., Chętnicki W. \& Kupryjanowicz J., 1989: Small mammals of Gorce National Park. Acta zool. cracov., 32: 631-652. - Buchalczyk T. \& Markowski J., 1979: Ssaki Bieszczadów Zachodnich. Ochr. Przyr., 42: 119-150. - Chudoba S. \& Haitlinger R., 1971: Drobne ssaki Beskidu Żywieckiego. Acta zool. cracov., 16: 413-433. - Chudoba S., Haitlinger R. \& Humiński S., 1973: Drobne ssaki Sudetów Zachodnich. Przegl. zool., 17: 111-121. - Chudoba S. \& Humiński H., 1968: Owadożerne i gryzonie Beskidu Sądeckiego. Acta zool. cracov., 13: 213-230. — Grodziński W., 1957: Materiały do fauny kręgowców Bieszczad Zachodnich. Zesz. nauk. U. J. Zool., 10: 177-221. - Haitlinger R., 1970: Morphological characters of mountain populations of Clethrionomys glareolus (Schreber, 1780) and Apodemus agrarius (Pallas, 1773). Acta theriol., 15: 269-282. - Haitlinger R. \& Szyszka K., 1975: Drobne ssaki Pienińskiego Pasa Skałkowego. Acta zool. cracov., 20: 185-200. - Haitlinger R. \& Szyszka K., 1977: Drobne ssaki Gorców, Pasma Radziejowej i niektórych obszarów sąsiednich. Przegl. zool., 21: 155-170. - Juchiewicz M., Zemanek M., Bieniek M. \& Siuta E., 1986: Small rodent communities in the Tatra Mountain forests. Acta theriol., 32: 433-447. Kałuża T., 1987: Stanowisko orzesznicy Muscardinus avellanarius (Linnaeus, 1758) w Wielkopolsce. Przegl. zool., 31: 215-218. - Pelikán J., Gaisler J. \& Rödl P., 1979: Naši savci. Ćeskosl. akad. ved.: 1-163. Praha. - Pucek Z. (ed.), 1984: Klucz do oznaczania ssaków Polski. Państw. Wyd. Nauk.: 1-384. Warszawa. - Sidorowicz J., 1959: Über Morphologie und Biologie der Haselmaus (Muscardinus avellanarius L.) in Polen. Acta theriol., 3: 75-91. - Siivonen L., 1979: Mlekopitajuščije Severnoj Evropy. Izd. Lesnaja Promyšlennost: $1-231$. Moskva.

Received 19 April 1988, Accepted 15 May 1989. 